\title{
CHURCH HISTORY IN SCIENTIFIC RESEARCHES OF P. MYKHAILO ZUBRITSKYI
}

\author{
Микола ТУГАЙ \\ Державний вищий навчальний заклад \\ "Прикарпатський національний університет імені Василя Стефаника" \\ кафедра етнології і археологї, \\ вул. Шевченка, 57, 76018, Івано-Франківськ, Україна \\ e-mail: tmikola69@gmail.com \\ DOI: 10.15330/gal.33.168-176 \\ ORCID: 0000-0001-5540-2953
}

У статті проаналізовано науковий доробок отия Михайла Зубрицького (1856-1919) з вивчення церковної історї та релігійної проблематики. Автор визначає проблематику досліджень отия Михайла через аналіз його науково-публіщистичних пращь. Констатовано, щчо свої наукові дослідження він будував на основі даних єпархіальних та деканатських архівів та бібліотек а також згідно власних спостережень. Відзначено, щзо наукові напрацювання слід умовно розділити на три підгрупи: археографічні, аналітичні та історичні. До першої групи прачь належать публікачії архівних документів та матеріалів, зокрема низку иерковних актів та офіційних документів, до другої - висвітлення иерковних відносин, взаємин між священниками та між віруючими та священнослужителями, відповідно до третьої групи належать праці історичного змісту, у яких автор подав відомості з історії иеркви в Галичині та сусідніх територій а також історії окремих парохій краю. Встановлено археографічну та історичну цінність віднайдених матеріалів, які є значущим джерелознавчим матеріалом у дослідженні иерковної історії та проблематики Галичини.

Відзначено, щчо негативним явищем в иерковних справах наприкінці XIX - початку XX cm. ma історії отець Михайло вважав москвофільство та переходи громад на латинських обряд. Наголошено, щчо на його думку, иее несе загрозу для єдності руського народу, а також не сприяє його розвитку. Слід наголосити, народознавець одночасно ставав на захист сільського духовенства, проте, критикує їх за слабкий зв'зок із місиевим населенням та не активність у громадсько-культурній роботі. Відзначимо, щзо дослідник недостатньо критично піддавав аналізу використані документи, а здійснював тільки їх публікації. Зазначається, щзо дана тематика лише частково висвітлена у наукових напрачюваннях вітчизняних та зарубіжних дослідників.

Ключові слова: Михайло Зубрицький, церкква, москвофільство, єпархія, священик, Ставропігія, духовенство.

Formulation of the problem. A separate page in the scholarly work of the well-known Ukrainian ethnographer Priest Mykhailo Zubrytskyi i (1856-1919) was devoted to the study of the history of the church and the coverage of the daily life of the clergy. As a priest, he had access to diocesan libraries and archives, allowing him to process ancient materials that he subsequently published on the pages of scholarly journals of that time.

An analysis of the main research of publications. Church history in the study of Priest Mykhailo Zubrytskyi has been poorly studied until recently, so today there is no generalizable work in Ukrainian historical and ethnological science in which his research activity is analyzed. However, the work of Ukrainian researchers Hryhorii. Demian and Andrii Zaiarniuk and the Canadian scientist Frank Sysin should be singled out, in which they partially analyze the publications of the natural scientist on this problem.

As the Ukrainian researcher G. Demian rightly noted, this work of the natural scientist was skillfully used to encourage his colleagues to patriotic work ${ }^{1}$.

\footnotetext{
${ }^{1}$ Дем'ян Г. Маловідомі сторінки життя і наукової праці Михайла Зубрицького. Записки НТШ. Праиі секції етнографї̈ та фольклористики. 1992. Т. ССХХІІІ. С. 181.
} 
Setting objectives. The purpose of the article is to review and analyze the scientific achievements of Priest Mykhailo Zubrytskyi i in the study of church history.

Presenting main material. On the basis of archival materials, priest M. Zubrytskyi i issued a large number of documents concerning the clergy and parishes of the region under his own name ${ }^{2}$. Priest Mykhailo Zubrytskyi's publications on church history and the problems of the church, in our opinion, should be conditionally divided into three groups: archeographic, analytical and historical.

The first group of publications of the researcher should include works of archaeographic content, in which priest Mykhailo published documents and materials on the history of the church and church problems, found in decanal and diocesan archives and libraries.

Among the valuable documents found by priest M. Zubrytskyi $i$ is the "Chronicle of Stavropygy", , the original of which is in the funds of the Institute of Literature of the National Academy of Sciences of Ukraine - Stavropigian University (since 1788).

A considerable array of documents and correspondence of priest Mykhailo Zubrytskyi i was published on the occasion of the opening of deanery and parish libraries for the years $1825-1854^{4}$, which contained almost as much of his own analysis as the publication and summation of documents ${ }^{5}$, as well as the state of the Greek Catholic clergy at the peak of its Polonization in Galicia ${ }^{6}$. As the Canadian scientist F. Sysin points out, this collection demonstrated the devotion with which the hierarchy supported the Russian language ${ }^{7}$. A series of documents were published by a researcher regarding the refusal of peasants to sign petitions for the return of land to church and parish property. The scientist found petitions from the villages of Hvizdets, Limna and Khashchov in the Turkiv region. People "justified the refusal of signatures for fear of betrayal, b. the return of the serfdom".

His general interest in the history of education prompted him to publish the documents of a Galician Greek Catholic dean from the early 19th century". In the collection "Materials to the cultural history of Galician Rus XVII and XVIII centuries, collected by M. Zubrytskyi, Jur. Mayor, Eve. Kobyletskyi, Iv. E. Levitskyi and Yves. Frank" priest Mykhailo Zubrytskyi placed documentary materials on the history of the school and the first Ukrainian educational society that existed in 1816$1818^{10}$.

Among the archeographic works on this topic should be highlighted the publication of "Sale of" half "in the village. Skopje in 1592" about the sale of Stanislav Tarnavskyi to Yatskova Telesnitskyi for $266 \mathrm{zf}^{12}$, also a list of duties (natural and labor) performed by the peasants in favor of the priest.

In addition to the case of the sale of a half-family, priest Mykhailo has documented at least four such cases on the basis of processed documents. The first of which dates from 1637, where

\footnotetext{
2 Зубрицький М. Зібрані твори і матеріали : у 3 т. / редкол. Франк Сисин та ін. Вид. 2-е, випр. Львів, 2019. Т. 1 : Наукові праці. 610 с.

${ }^{3}$ Відділ рукописних фондів і текстології Інституту літератури ім.Т. Г. Шевченка НАН України (далі - ІЛ). Ф. 3. Іван Франко. Спр. 3323. Зубрицький [] Хроніка Ставропигії. Виписки з хроніки за 1662-1699 рр. Львів, 17.IX.1841. Рукопис невідомою рукою польською мовою. 1 арк.

${ }^{4}$ Зубрицький М. Деканальні й парохіяльні бібліотеки Перемиської епархії. Записки НТШ. 1909. Т. ХС. Кн. IV. C. 119-136.

5 Зубрицький М. Зібрані твори і матеріали. Т. 1. С. 38.

${ }^{6}$ Зубрицький М. Причинки до історії руського духовенства в Галичині від 1820-1853 рр. Записки НТШ. 1909. T. LXXXVIII. Кн. II. C. 118-150.

7 Зубрицький М. Зібрані твори і матеріали... Т. 1. С. 38.

${ }^{8}$ Зубрицький М. Парохіяни відмовлюють підписів на петицію против відобраня церковних і парохіяльних дібр в 1848 р. [додаток: оригінальні тексти документів]. Записки НТШ. 1904. Т. 57. Кн. І. С. 6-8.

9 Зубрицький М. Зібрані твори і матеріали. Т. 1. С. 38; Зубрицький М. Перехід руської громади на латинський обряд (допись з Старосамбірщини). Діло. 1907. 28 лютого (13 марта). Ч. 47. С. 2.

10 Зубрицький М. Зібрані твори і матеріали : у 3 т. / редкол. Франк Сисин (голова) та ін. 2016. Львів. Т. 2 : Матеріали до біографії. $616 \mathrm{c}$.

${ }^{11}$ Зубрицький М. Продажа “попівства” в с. Скопові 1592 р. Записки НТШ. 1898. Т. XXV. Кн. V. С. 1-2.

12 Зубрицький М. Добродійство польської шляхти для руської церкви і руського духовенства. Діло. 1902. 10 (23) грудня. Ч. 275. С. 1; 11 (24) грудня. Ч. 276. С. 1-2.
} 
Vladyslav Zelensky sold Ivanov in Zalich for 200 zł. $^{13}$, the next case of the sale of the insurgency took place in 1642, according to which Martin Krasitsky sold the insult to Mikhailov in Hirina for $400 \mathrm{zt}^{14}$. In 1650, the third such incident occurred. In Rushelchichi for $400 \mathrm{zk}$., A sale was made to Felician Grokhovsky by Gregory Timkovich ${ }^{15}$. And in the last case of the sale of the half-breed the researcher recorded in 1668 for 150 zł. Nikolay Firley in Grechpol sold Vasyl Paslavsky ${ }^{16}$. Priest Mykhailo emphasized that "the sale of the half-breed was common in Poland"17.

On the basis of the book "Acta revisionis ecclesiarum intra decanatum..." Zubrytskyi i published materials on the situation of the clergy and churches. The author points out that the number of parishes decreased "by that time there were 30, but now there are no 10 "19. The reason for this, he pointed to the transition of the population to the Latin rite and the decline of "spiritual". On the basis of the sources, the author described the duties of the peasants for the benefit of the priests in different villages of the region (Pnovnichi, Bakhiv, Rushelchichi, Sinnin, Riplin) ${ }^{20}$. The arbitrariness of Polish and insulted landowners, the onslaught of the Roman Catholic clergy, poverty and the feudal dependence of the peasantry - all the information submitted by the scientist, according to G. Demian, led to the gradual degradation of part of the Ukrainian priests ${ }^{21}$.

A series of documents on the history of local clergyin the XVI century collected by priest Mykhailo Zubrytskyi, were published on the pages of NTSH Notes ${ }^{22}$. The paper contains documents of village parishes, namely: Zamikhiv, Khyryna, Rushelchychi, Grechpil, Yatkovichi, Dubkovychi (now the territory of the Polish Republic) ${ }^{23}$, as well as the position of the clergy and relations with peasants, etc.

To the greatest achievements of Priest Mykhailo in the history of religion in the nineteenth century and religious relations between Galicia and the Ukrainian lands within the Russian Empire are the publication of letters from the Galician priestly family from under Mshanets, which in the 70's of the XIX century moved to the Kholmshchyna ${ }^{24}$. Priest Mykhailo Zubrytskyi published letters from the priest S. Salvitsky to the priest A. Nazarevich in Mshanka with information about the transition of part of the clergy from Galicia to the Holm region went at the end of the 60s and in the first half of the 70s of the last century, the Russian clergy from Galicia to the Hill to convert their Uniates to Orthodoxy" 25 .

The second group of ecclesiastical researcher's works is analytical content. In them, Priest Mykhailo Zubrytskyi analyzed church relations, information about priests, relationships between ordinary people and clergy, as well as the place of the clergy in the historical events of the nineteenth century.

One of the first works of a researcher on church topics called "Notes in the Servant printed in 1666 "26 was published in 1889 on the pages of the newspaper "Zoria" in 1889 . The content of the article reflects information about priests, their appointments and changes, data on marriages and deaths

\footnotetext{
13 Зубрицький М. Добродійство польської шляхти для руської церкви і руського духовенства... С. 1.

14 Там само. С. 1.

15 Там само. С. 1.

16 Там само. С. 1.

${ }^{17}$ Там само. C. 1 .

18 Acta revisionis ecclesiarum intra decanatum Pruchnicensem comsistentium. Item inventaria, decreta reformationum circa eandem revisionem, ac decreta controversiarum continentia. Per me Danielem Zatwarnicki, ejusdem loci Decanum anno Domini 1765 die 9 Januarii compleri coepta.

19 Зубрицький М. Знадоби для характеристики життя світського гр. кат. духовенства в Галицькій Русі в XVIII в. Матеріали до культурної історії Галицької Руси ХVII і ХІХ віку, зібрані Мих. Зубрицьким, Юр. Квітом, Ів. Кобилецьким, Ів. Е. Левицьким і Ів. Франком / під редакцією Івана Франка. 1902. С. 18.

${ }^{20}$ Там само. С. 23.

${ }^{21}$ Дем'ян Г. Маловідомі сторінки життя і наукової праці Михайла Зубрицького... С. 181.

22 Зубрицький М. Кілька документів до історії сільського духовенства в Галичині XVII-XVIII вв. Записки HTШ. 1903. T. LI. Кн. 1. С. 2-12.

${ }^{23}$ Там само. С. 4.

24 Зубрицький М. Зібрані твори і матеріали. Т. 1. С. 37-38.

25 Зубрицький М. Галицькі священики в Холмщині. Записки НТШ. 1908. T. LXXXIV. Кн. IV. C. 174.

26 Зубрицький М. Записки в Служебнику печатанім 1666 року. Зоря. 1889. 1 (13) липня. Ч. 13 і 14.

C. $322-234$.
} 
of different persons. Priest Mykhailo pointed to the great value of church history, since "the shematism of the peremiskoi diocese of the years 1877, 1879 and 1880 avenged a large number of literacy"27.

In The Right Prizes of Priests, Priest Mykhailo focuses on the difficult socio-economic situation of priests who have no protection from the local secular intelligentsia. The researcher emphasized that the priests did little work for the people's cause: "If all the priests had united together and worked together for the good of their people, the Russian cause would soon go to the front" ${ }^{28}$. At the same time, he expressed his dissatisfaction with the election of the priests to the deeds, stating that "the present right is quite bad, because it seeks to please the uncle, and the peasants must remain silent. This is no wonder, because this right was established and approved by the uncles" 29 .

Particularly valuable is the publication of priest Mykhailo Zubritskyi about Bishop Ivan Snegursky, who was called "by far the greatest bishop of the Diocese of Peremogy" 30 through his active work and struggle for the Ukrainian people. The scientist analyzed the works dedicated to the memory of the bishop. Among such works, he distinguished the following works: priest Ivan Naumovich and priest Justine Zhelekhovsky. The researcher himself points out that "this was a living man, who was deeply moved by the disgust of working sincerely for the renewal and revival of his so very unhappy people" ${ }^{\text {"31 }}$.

The scientist published the relations between the peasants and the monks of the Lavra Monastery in the Dilo newspaper. Priest Mykhailo states that "though they have great expanses of land, they enter into a dispute with the peasants about the land"32. The monks support the elder, but the local Hrytsak family opposes giving the land to the monks. The family was sentenced to prison for this. The researcher also submitted the Starostin decision on this situation in the publication ${ }^{33}$.

Publication "Letter from priest Lomnitsky from Kromerizh in $1848^{\text {"34 }}$ priest Mykhailo submitted materials to characterize the impact of the revolutionary events of 1848 on the outlook and actions of the Ukrainian clergy in Galicia, its national consciousness ${ }^{35}$.

To the third group of publications of priest Mikhailo, include the work in which he provided historical information on the history of the church in Galicia, the history of individual parishioners of the land and more.

A separate part of priest Mykhailo Zubrytskyi dedicated the history of a separate religious community - a parish, a scholar published a note in the newspaper "Dilo" for 1895 , also in "ZNTSh" ". An example of such a community were the Lopushnitsa parish in the Dobromyl district and the Ripnik parish in the Korosnia Deanery. In the first parish, the scientist mentioned two priests: priest Vladislav Pope (from 1850 to 1871), priest Vasyl Bachynsky (from 1873 to 1894) ${ }^{37}$. Describing each of them, the ethos scientist points out: "While you were a parish priest, priest Dad, everything was going fine. Powder draws all to sobriety, and when anyone is drunk, have to buy beer in the church under the church"..."people drank some of the vodka at least" ${ }^{\prime 38}$. He stressed that everything changed for the new gunpowder. "Bachinsky often does not brave anything for the services of a parochial, and when it is brave, it is very small, but it is not very busy with its parishioners. The

\footnotetext{
27 Зубрицький М. Записки в Служебнику печатанім 1666 року. Зоря. 1889. 1 (13) липня. Ч. 13 і 14. С. 233.

28 Зубрицький М. Право призенти сьвященників. Батьківщчина. 1895. 16 (28) червня. Ч. 11, 12. С. 87.

${ }^{29}$ Там само. С. 88.

30 Зубрицький М. П'ятдесята річниця смерти бл. п. епископа Івана Снігурського. Написав Михайло Зубрицький. Діло. 1897. 7 (19) мая. Ч. 102. С. 1.

${ }^{31}$ Там само. С. 1.

32 Зубрицький М. 3 Староміського пишуть нам: Прикрі відносини панують в селі Лаврові межи лаврівськими моназами а селянами... Діло. 1901. 22 лютого (7 марта). Ч. 42. С. 2.

${ }^{33}$ Там само. С. 2.

34 Зубрицький М. Письмо о. Ломницького з Кромерижа 1848 р. Зоря. 1888. 1 (13) листопада. Ч. 21. С. 358-359.

35 Дем’ян Г. Маловідомі сторінки життя і наукової праці Михайла Зубрицького... С. 182.

36 Зубрицький М. Парохія Лопушниця в Добромильськім повіті. Діло. 1895. 14 (26) жовтня. Ч. 231. С. 1-2; Зубрицький М. Канонічний огляд парохії Ріпник в Короснянськім деканаті в Галичині в 1870 р. Записки HTU. 1912. T. CVII. Кн. I. C. 119-128.

37 Зубрицький М. Парохія Лопушниця в Добромильськім повіті... С. 1.

${ }^{38}$ Там само. С. 1.
} 
church began to fall, people had no place to go. The parishioners did not hear the sermons and teachings of the church outside the church, rarely when they came together, and when anyone appeared, he was sent to the prison" 39 . In a letter to the editorial office of the Dilo newspaper, Priest Mykhailo said that he himself saw the situation in the parish, and also heard something from people ${ }^{40}$. Concerning the second parish - Ropnik, the ethnographer publishes materials on its review, the confession of the peasants about the beating of the nobleman Grabkovskyi local priest, etc ${ }^{41}$. Summarizing the intelligence data, the author stated that "it will be a precaution for people to work more over the people" ${ }^{, 4}$.

In his reports, articles, speeches of priest Mykhailo Zubrytskyi defended the clergy. The radical congress of 1897 in Lviv, where priests received the most negative feedback, was no exception. He emphasized, "the gradual people did not once and not two grumble about the intolerance of the church and its servants; more than one did not like the fact that the church had summoned other people who thought differently, and that they pursued and heartlessly pursued it" ${ }^{43}$. At the congress, "priests" was called the greatest misfortune of our peasants, and with this opinion the researcher disagreed and cited the following: "the lack of peasants for years will not give a crusader to keep the priest" ${ }^{44}$. He also protected the priests from being unable to preach Marx and Lassalle in the church.

The scientist praised the activity of priest Grytsykevych, giving him the following characteristic: "This is not an evil priest and would gladly help the people's cause" 45 . Also, such priests include Priest Jaworski, who, according to Priest Mykhailo Zubrytskyi, was "a man of resolute and kind Rusyn" ${ }^{46}$, emphasizing his skillful cultural and political activities ${ }^{47}$.

In one of the following articles, Priest Mykhailo Zubrytskyi reproached the secular Ukrainian intelligentsia: "the Russian, especially the secular intelligentsia, do not have the least influence on the lower strata of the Russian population" 48 and the clergy "are more in contact with the people from their official duties, and those who live in the countryside converge even more with their parishioners" Snigurski (1846), who defended himself against Polish chauvinists. The author summed up "the most spiritual men come to battle, earnestly labor for the good of their people" ${ }^{50}$ and "a capable priest can become the focal point of the whole village of the parish",51.

Priest Mykhailo criticized priest Mykhailo Pruhnitsky of Turka in one of his publications ${ }^{52}$. He emphasized that the priest, apart from purely ecclesiastical affairs, did not engage in social and cultural work among the population of Turks and Melnychny. The researcher emphasized that "it would be good for other intelligent forces, especially priests, to take up work" ${ }^{, 53}$.

\footnotetext{
39 Зубрицький М. Парохія Лопушниця в Добромильськім повіті... С. 1.

40 ІЛ. Ф. 100 (Белей І. М.). Од. зб. 1704. (Зубрицький Михайло. Лист до редакції газети “Діло”. Мшанець. 23. Х. 1895 р. автограф), 1 арк.

41 Зубрицький М. Канонічний огляд парохії Ріпник в Короснянськім деканаті в Галичині в $1870 \ldots$

42 ІЛ. Ф. 100. Од. зб. 1704. Арк. 1.

43 Зубрицький М. Деякі замітки над нарадами радикалів на з’їді у Львові. (Письмо з села). Діло. 1897. 13 (25) жовтня. Ч. 232. С. 1.

${ }^{44}$ Там само. С. 1.

45 ІЛ. Ф. 100 (Белей І. М.). Од. зб. 1701 (Зубрицький Михайло. Лист до [....]. Мшанець. 3.XI. 1894 р. автограф). Арк 2.

${ }^{46}$ ІЛ. Ф. 100 (Белей І. М.). Од. зб. 1709 (Зубрицький Михайло. Лист до редакції газети “Діло”. Мшанець. 11.ІХ.1896 р. автограф). Арк 1.

${ }^{47}$ ІЛ. Ф. 100 (Белей І. М.). Од. зб. 1703 (Зубрицький Михайло. Лист до редакції газети “Діло”. Мшанець. 7.Х. 1895 р. автограф). Арк 1; ІЛ. Ф. 100 (Белей І. М.). Од. зб. 1710 (Зубрицький Михайло. Лист до редакції газети “Діло”. Мшанець. 13.XII.1896 р. автограф). 2 арк.

48 Зубрицький М. В історії нераз дещо повторює ся. Діло. 1902. 29 мая (11 червня). Ч. 119. С. 1.

${ }^{49}$ Там само. С. 1.

${ }^{50}$ Там само. С. 2.

51 Зубрицький М. Зь села (Деякі гадки до розваги нашим матуристам). Діло. 1895. 22 липня (3 серпня). Ч. 162. С. 2

52 Зубрицький М. Письмо з Турки коло Хирова. Діло. 1902. 8 (21) січня. Ч. 6. С. 2.

53 Там само.
} 
Priest Mykhailo Zubrytskyi was particularly negative about Moscow philosophers. The researcher condemned the actions of the Moskophiles priests Roman Krushynskyi of Leninka and Dmitry Marchak of Golovetskyi, stating that they were writing documents in Polish, and that the only one who was writing in Russian was Fr. Ivan the Economic, the gunner in Galivka ${ }^{54}$. Under the very title of the publication Moskophiles on the Services of Poland, he noted that the Moskophiles priests "became Polish patriots and forgot entirely about their" Russian "patriotism" "55. He praised the activity of Priest Prelat Voytovich, who, as a member of the district school council, "did not care about the science of Russian" analphabets" $" 57$. Priest Mykhailo Zubritsky positively covered the activity of Bishop Sylvester Sembratovich, who was "so unloved by Muscophiles" who performed "low revenge" on the priest ${ }^{58}$.

In one of his publications, the researcher stated the reasons for the loss of respect for clergy among people. He attributed to them, above all, the activities of the priests themselves ${ }^{59}$. The scientist argued that the priest should deliberately work for the benefit of the community and the entire people, contribute to raising the conditions and standard of living of the peasant ${ }^{60}$. It should be added that 1846 was a year of propagation of aticlerical agitation and sentiment, which resulted in the spread of songs among peasants directed against both priests and landowners ${ }^{61}$.

The ethnographer's process of Catholicization of the Ukrainian population of Galicia and the transition from one rite to another also did not help. In particular, one of these transitions was recorded and published by priest M. Zubritskyi. The peasants of the Sunday Sambir County "in order to have their spiritual priest announce the conversion to Latin",62, since "they had only a third Sunday to go to church, and to the parish church to go far" ${ }^{\prime 63}$.

At the same time, the transition from Roman Catholic rite to Greek Catholic was in every way prevented by the leadership of the elderly. One such case was published by Priest Mykhailo Zubrytskyi under the title "Not equal measure" ". In it, the researcher described the fact of a young man's transition from a Greek Catholic rite to a Roman Catholic one and a ban on the opposite. The Sambir Commissioner of Torsk, resorting to a sophisticated interpretation of the legal provisions on this issue: "for the law knows the transition from religion or belief to another faith, but not from ritual to ritual of the same faith" ${ }^{35}$. In the end, Priest Mykhailo successfully summarized this case "from the Russian rite to the Latin to freely go, because the law does not allow, but the same state law does not allow to move from the Latin to the Russian rite" $" 66$.

In one of priest Mykhailo Zubritsky drew attention to such a phenomenon as pilgrimage. In particular, he gave an example of a pilgrimage of people from Rus to Calvary or Calvary, who were very popular. This was used by the Franciscan monks, who "conceived at their churches to build chapels, inheriting the buildings at Calvary and called them also Calvary" ${ }^{\prime \prime 7}$. According to the records of a scientist in Galicia there were two such places "one circle Wadowice in Zebrzydow and the other on Paclav circle Dobromyl" ${ }^{\prime 68}$. In order to increase the number of pilgrims to these places, rumors

\footnotetext{
54 Зубрицький М. Москвофіли на услугах польщини. Діло. 1902. 15 (28 червня). Ч. 133. С. 3.

55 Там само. С. 3.

56 Зубрицький М. Москвофільство в ієрархії. Діло. 1903. 27 падолиста (10 грудня). Ч. 268. С. 2.

57 Там само. С. 2.

58 Зубрицький М. Епохальна приключка у москвофілів. Діло. 1902. 6 (19) липня. Ч. 148-149. С. 2.

${ }^{59}$ Зубрицький М. Зь села... С. 2.

${ }^{60}$ Там само. С. 2.

${ }^{61}$ Заярнюк А. Ідіоми емансипації. "Визвольні” проєкти і галицьке село в середині ХІХ. Київ : Критика, 2007. C. 49

62 Зубрицький М. Перехід руської громади на латинський обряд... С. 2.

${ }^{63}$ Там само. С. 2.

${ }_{65}^{64}$ Зубрицький М. Не рівна міра. Діло. 1899. 24 жовтня (6 падолиста). Ч. 240. С. 1.

${ }^{65}$ Там само. С. 1.

${ }^{66}$ Там само. С. 1.

67 Зубрицький М. Богомольні походи в Кальварію, коло Добромиля. Батьківщина. 1892. 24 липня (5 серпня). Ч. 30. С. 150.

${ }^{68}$ Там само. С. 150.
} 
spread that "the one on Holy Calvary tortured Jesus Christ", to which Priest Mykhailo replied: "not on Patslav, good people, tortured Christ, but on Calvary, the mountain near Jerusalem"69. Thus, he denied the "sanctity" of the local Calvary and warned people against ill-advised expenses, because most of their money (donations and so on) was left to the "shinkar Jews".

Conclusions. The study found that a lot of space in his studies, Priest Mykhailo Zubrytskyi devoted problems and history of the church. His works are rich in archeographic, analytical and historical content, which covers a variety of pages in the history of the church of Galicia. The peculiarities of the church relations between the priests themselves and between parishioners and clergy are highlighted. At the same time, previously unknown pages from the history of individual parishes in the region have been uncovered. Priest Mykhailo supported and praised the clergy's sociocultural and political activities, but criticized them for not being too active in the community. $\mathrm{He}$ particularly evaluated the activities of Muscophiles and the transitions of communities from one rite to another. Previously unpublished materials authored by Priest Mykhailo Zubrytskyi are involved in the work-correspondence and church chronicles.

The results of the research can be used for further research of church history and issues in Galicia, with the subsequent involvement of historiographical and source material.

\title{
CHURCH HISTORY IN SCIENTIFIC RESEARCHES OF P. MYKHAILO ZUBRITSKYI
}

\author{
Mykola TUHAI \\ State Higher Educational Institution \\ "Vasyl Stefanyk Precarpathian National University", \\ Department of ethnology and archeology, \\ Shevchenko St., 57, 76018, Ivano-Frankivsk, Ukraine \\ e-mail: tmikola69@gmail.com
}

\begin{abstract}
Summary
The article deals with the scientific achievements of Priest Mykhailo Zubrytskyi (1856-1919) in the study of church history and religious issues. He stated that he had based his research on the data of the diocesan and deanery archives and libraries, as well as on his own observations. It is noted that scientific work should be conditionally divided into three subgroups: archeographic, analytical and historical. The first group of works includes the publication of archival documents and materials, including a number of church acts and official documents the second - the coverage of church relations, relations between priests and between believers and clergy, according to the third group include works of historical content, in which the author provided information on history of the church in Galicia and neighboring territories, as well as the history of individual parishioners of the region.

The archeographic and historical value of the materials found has been established. It is noted that Priest Mykhailo considered the phenomenon of church affairs and history to be Muscophilic and the transitions of communities into Latin rites. He believed that this was a threat to the unity of the Russian people and also not conducive to its development. It should be emphasized that the historian at the same time stood up for the protection of the rural clergy, but criticized them for their weak connection with the local population and not active in social and cultural work. Note that the researcher was not critical enough to analyze the documents used. It is noted that this topic is only partially covered in the scientific work of domestic and foreign researchers.
\end{abstract}

Keywords: Mykhailo Zubrytskyi, church, Muscophilism, diocese, priest, Stavropigia, clergy.

\section{REFERENCES}

Demian H. (1992). Malovidomi storinky zhyttia i naukovoi pratsi Mikhaila Zubrytskoho [Little-known pages of the life and scientific work of Mykhailo Zubrytskyi ]. Zapysky NTSh. Pratsi sektsii etnohrafii ta folklorystyky, vol. CCXXIII, pp. 172-196 (in Ukrainian).

\footnotetext{
69 Зубрицький М. Богомольні походи в Кальварію, коло Добромиля. Батьківщзина. 1892. 24 липня (5 серпня). Ч. 30. С. 150.
} 
Demian H. (2008). Natsionalno-derzhavnytske spriamuvannia diialnosti Mykhaila Zubrytskoho (Tematyko-bibliohrafichnyi ohliad publikatsii) [National-state direction of Mykhailo Zubrytskyi 's activity (Thematic and bibliographic review of publications)]. Narodoznavchi zoshyty, no. 3-4, pp. 358-372 (in Ukrainian).

Department of Manuscripts and Textology of the Taras Shevchenko Institute of Literature of the National Academy of Sciences of Ukraine (hereinafter - IL). F. 100. Beley. I M. Od. zb. 1701. Mykhailo Zubrytskyi. Letter to [....]. Mshanets. 3.XI. 1894 autograph 4 ark.

IL. F. 100. Beley. I M. Od. zb. 1703. Mykhailo Zubrytskyi. Letter to the editorial office of the newspaper "Dilo". Mshanets. 7.X. 1895 autograph. 2 ark.

IL. F. 100. Beley. I M. Od. zb. 1704. Mykhailo Zubrytskyi. Letter to the editorial office of the newspaper "Dilo". Mshanets. 23. H. 1895 autograph. 1 ark.

IL. F. 100. Beley. I M. Od. zb. 1709. Mykhailo Zubrytskyi. Letter to the editorial office of the newspaper "Dilo". Mshanets. 11.IX.1896 autograph. 1 ark.

IL. F. 100. Beley. I M. Od. zb. 1710. Mykhailo Zubrytskyi. Letter to the editorial office of the newspaper "Dilo". Mshanets. 13.XII.1896 autograph. 2 ark.

IL. F. 3. Ivan Franko. Spr. 3323. Zubrytskyi [] Chronicle of Stauropygia. Extracts from the chronicle for 1662-1699. Lviv, 17.IX.1841. Manuscript by an unknown hand in Polish. 1 ark.

Sysyn E. Frank. (2012). Religion within the Ukrainian Populist Credo: The Enlightened Pastor Mykhailo Zubrytskyi. Journal of Ukrainian Studies, vol. 37, pp. 85-96 (in Ukrainian).

Zaiarniuk A. (2007). Idiomy emansypatsii. "Vyzvolni” proiekty i halytske selo v seredyni XIX. [Idioms of emancipation. "Liberation" projects and the Galician village in the middle of the XIX century]. Kyiv: Krytyka (in Ukrainian).

Zubrytskyi M. (1888, 1 (13) lystopada). Pysmo o. Lomnytskoho z Kromeryzha 1848 r [Letter from Fr. Lomnytsky from Kromeriz in 1848]. Zoria, part 21, pp. 358-359 (in Ukrainian).

Zubrytskyi M. (1889, 1 (13) lypnia). Zapysky v Sluzhebnyku pechatanim 1666 roku [Notes in the missal printed in 1666]. Zoria, part 13, 14, pp. 322-234 (in Ukrainian).

Zubrytskyi M. (1892, 24 lypnia (5 serpnia).) Bohomolni pokhody v Kalvariiu, kolo Dobromylia [Worship trips to Calvary, near Dobromil]. Batkivshchyna, part 30, pp. 150-151 (in Ukrainian).

Zubrytskyi M. (1895. 16 (28) chervnia.). Pravo pryzenty sviashchennykiv [The right to present priests]. Batkivshchyna, part 11, 12, pp. 87-88 (in Ukrainian).

Zubrytskyi M. (1895, 14 (26) zhovtnia). Parokhiia Lopushnytsia v Dobromylskim poviti [Parish of Lopushnytsia in Dobromil County]. Dilo, part 231, pp. 1-2 (in Ukrainian).

Zubrytskyi M. (1895, 22 lypnia (3 serpnia)). Z sela (Deiaki hadky do rozvahy nashym maturystam) [From the village (Some hints for fun for our graduates)]. Dilo, part 162, p. 2 (in Ukrainian).

Zubrytskyi M. (1897, 13 (25) zhovtnia). Deiaki zamitky nad naradamy radykaliv na zizdi u Lvovi. (Pysmo z sela) [Some notes on the meetings of radicals at the congress in Lvivю (Letter from the village)]. Dilo. ch. 232, pp. 1-2 (in Ukrainian).

Zubrytskyi M. (1897. 7 (19) maia, part 102; 8 (20) maia, part 103; 10 (22) maia, part 105). Piatdesiata richnytsia smerty bl. p. yepyskopa Ivana Snihurskoho. Napysav Mykhailo Zubrytskyi [The fiftieth anniversary of the death of approx. Mr. Bishop Ivan Snigurskyi. Written by Mykhailo Zubrytskyi]. Dilo, no. 1-2; 1-2; 1-2 (in Ukrainian).

Zubrytskyi M. (1898). Prodazha "popivstva" v s. Skopovi 1592 r. [Sale of "populism" in the village. Skopov in 1592] Zapysky NTSh, vol. XXV, b. V, pp. 1-2 (in Ukrainian).

Zubrytskyi M. (1899. 24 zhovtnia (6 padolysta)). Ne rivna mira [Not an equal measure]. Dilo, part 2401 (in Ukrainian).

Zubrytskyi M. (1901, 22 liutoho (7 marta). Ch. 42). Z Staromiskoho pyshut nam: Prykri vidnosyny panuiut $\mathrm{v}$ seli Lavrovi mezhy lavrivskymy monahamy a selianamy [From Staromysky write to us: Annoying relations prevail in the village of Lavrov borders by Lavrov monks and peasants]. Dilo, p. 2 (in Ukrainian).

Zubrytskyi M. (1902). Chotyry kurenty dekana Ihnata Dovydovycha z Radymna z d[nia] 9 i 10 maia 1816 r. [Four Kurents of Dean Ihnat Dovydovych from Radym on May 9 and 10, 1816.] v I. Franko. Materialy do istorii hal. Ruskoho shkilnytstva v rr. 1801-1848. V kn. Materialy do kulturnoi istorii Halytskoi Rusy XVIII XIX viku. Zibrani Mykh. Zubrytskyi m, Yur. Kmitom, Iv. Kobyletskym, Iv. E. Levytskym i Iv. Frankom. Vydani pid redaktsiieiu Ivana Franka. Lviv, pp. 206-214 (in Ukrainian).

Zubrytskyi M. (1902). Znadoby dlia kharakterystyky zhyttia svitskoho hr. kat. dukhovenstva v Halytskii Rusi v XVIII v [Needs to characterize the life of secular gr. executioner. clergy in Galician Rusy in the XVIII century]. Materialy do kulturnoi istorii Halytskoi Rusy XVII i XIX viku, zibrani Mykh. Zubrytskym, Yur. Kvitom, Iv. Kobyletskym, Iv. E. Levytskym i Iv. Frankom. Ivan Franko (Ed.), pp. 17-46 (in Ukrainian). 
Zubrytskyi M. (1902, 10 (23) hrudnia). Dobrodiistvo polskoi shliakhty dlia ruskoi tserkvy i ruskoho dukhovenstva [Charity of the Polish nobility for the Russian church and the Russian clergy]. Dilo, no. 1, part 275 (in Ukrainian).

Zubrytskyi M. (1902, 15 (28 chervnia)). Moskvofily na usluhakh polshchyny [Muscovites at the service of Poland]. Dilo, no. 3, part 133 (in Ukrainian).

Zubrytskyi M. (1902, 29 maia (11 chervnia). Ch. 119; 30 maia (12 chervnia). Ch. 120). V istorii neraz deshcho povtoriuietsia [Something is often repeated in history]. Dilo, 1; 2 (in Ukrainian).

Zubrytskyi M. (1902. 6 (19) lypnia). Epokhalna prykliuchka u moskvofiliv [A landmark adventure for Muscovites]. Dilo, part 148-149, p. 2 (in Ukrainian).

Zubrytskyi M. (1902. 8 (21) sichnia. Ch. 6). Pysmo z Turky kolo Khyrova [Letter from the Turka near Khirov]. Dilo, p. 2 (in Ukrainian).

Zubrytskyi M. (1903). Kilka dokumentiv do istorii silskoho dukhovenstva v Halychyni XVII-XVIII vv [Several documents on the history of the rural clergy in Galicia in the XVII-XVIII centuries]. Zapysky NTSh, vol. LI. b. 1, pp. 2-12 (in Ukrainian).

Zubrytskyi M. (1903. 27 padolysta (10 hrudnia)). Moskvofilstvo v iierarkhii [Muscoviteism in the hierarchy]. Dilo, part 268, p. 2 (in Ukrainian).

Zubrytskyi M. (1904). Parokhiiany vidmovliuiut pidpysiv na petytsiiu protyv vidobrania tserkovnykh i parokhiialnykh dibr v 1848 r [dodatok: oryhinalni teksty dokumentiv] [Parishioners refuse to sign a petition against the removal of church and parish oaks in 1848 [appendix: original texts of documents]]. Zapysky NTSh, vol. 57, b. I, pp. 6-8 (in Ukrainian).

Zubrytskyi M. (1907. 28 liutoho (13 marta). Ch. 47: Perekhid ruskoi hromady na latynskyi obriad (dopys z Starosambirshchyny) [The transition of the Rusy community to the Latin rite (letter from the Old Sambir region)]. Dilo, 2 (in Ukrainian).

Zubrytskyi M. (1908). T. LXXXIV. Kn. IV: Halytski sviashchenyky v Kholmshchyni [Galician priests in the Kholm region]. Zapysky NTSh, pp.173-183 (in Ukrainian).

Zubrytskyi M. (1909). Prychynky do istorii ruskoho dukhovenstva v Halychyni vid 1820-1853 rr [Reasons for the history of the $\mathrm{n}$ clergy in Galicia from 1820-1853]. Zapysky NTSh, vol. LXXXVIII, b. II, pp. 118-150 (in Ukrainian).

Zubrytskyi M. (1909). Dekanalni y parokhiialni biblioteky Peremyskoi eparkhii [Dean's and parish libraries of the Peremyshl diocese]. Zapysky NTSh, vol. XS, b. IV, pp. 119-136 (in Ukrainian).

Zubrytskyi M. (1912). Kanonichnyi ohliad parokhii Ripnyk v Korosnianskim dekanati v Halychyni v $1870 \mathrm{r}$ [Canonical survey of the parish of Ripnyk in the Korosnyansky deanery in Galicia in 1870]. Zapysky NTSh, vol. CVII, b. I, pp. 119-128 (in Ukrainian).

Zubrytskyi M. (2016). Collected Works and Materials. In 3 vol. Frank Sysyn (Ed.). Lviv, vol. 2: Materials for the biography (in Ukrainian).

Zubrytskyi M. (2019). Collected Works and Materials. In 3 vol. Frank Sysyn (Ed.). 2nd ed. Lviv, vol. 1: Scientific works (in Ukrainian).

Zubrytskyi M. (2019). Collected Works and Materials. In 3 vol. Frank Sysyn (Ed.). Lviv, vol. 3: Newspaper publications, ethnographic and archival materials (in Ukrainian). 